•方法・

\title{
中国大型真菌红色名录评估方法和程序
}

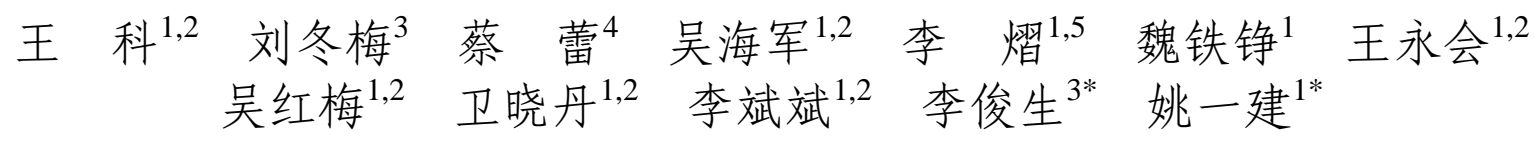

1 (中国科学院微生物研究所真菌学国家重点实验室, 北京 100101)

2 (中国科学院大学, 北京 100049)

3 (中国环境科学研究院国家环境保护区域生态过程与功能评估重点实验室, 北京 100012)

4 (生态环境部自然生态保护司, 北京 100035)

5 (扬州大学食品科学与工程学院, 江苏扬州 225127)

摘要: 在中国大型真菌红色名录评估过程中, 根据大型真菌与动植物在生物学特性上的差异, 对IUCN物种红色 名录标准做了适当调整, 形成了 “中国大型真菌红色名录评估等级与标准”, 即: (1)依据可见的分布地点和子实体 数量来估计、推测或判断种群的波动以及种群成熟个体数量的变化; (2)以一定的时间段代替世代时长来计算种群 的变化情况; (3)将 “疑似灭绝”作为一个独立的评估等级。评估基本数据来自于中国菌物名录数据库、真菌分类文 献资料和专家咨询, 评估过程包括任务分工、数据收集、评估物种确定、建立评估表、初评、专家评审和编制红 色名录等步骤, 最终完成《中国生物多样性红色名录一一大型真菌卷》的编制。

关键词: IUCN; 红色名录等级和标准; 疑似灭绝; 大型真菌; 评估过程

\section{Methods and procedures of the red list assessment of macrofungi in China}

Ke Wang ${ }^{1,2}$, Dongmei $\mathrm{Liu}^{3}$, Lei $\mathrm{Cai}^{4}$, Haijun $\mathrm{Wu}^{1,2}$, Yi $\mathrm{Li}^{1,5}$, Tiezheng Wei ${ }^{1}$, Yonghui Wang ${ }^{1,2}$, Hongmei $\mathrm{Wu}^{1,2}$, Xiaodan Wei ${ }^{1,2}$, Binbin $\mathrm{Li}^{1,2}$, Junsheng $\mathrm{Li}^{3 *}$, Yijian $\mathrm{Yao}^{1{ }^{*}}$

1 State Key Laboratory of Mycology, Institute of Microbiology, Chinese Academy of Sciences, Beijing 100101

2 University of Chinese Academy of Sciences, Beijing 100049

3 State Environmental Protection Key Laboratory of Regional Eco-process and Function Assessment, Chinese Research Academy of Environmental Sciences, Beijing 100012

4 Department of Nature and Ecology Conservation, Ministry of Ecology and Environment, Beijing 100035

5 School of Food Science and Engineering, Yangzhou University, Yangzhou, Jiangsu 225127

Abstract: In The Red List Assessment of Macrofungi in China project, the IUCN Red List Categories and Criteria were adjusted according to differences in biological characteristics among plants, animals, and macrofungi. The adjustments are as follows: (1) population fluctuation and mature population members were estimated according to visible distribution and fruiting bodies, (2) a certain time period (rather than generation time) was used to calculate population change, (3) Possibly Extinct was added as an additional threatened category. The assessed data was based on the Checklist of Fungi in China database, fungal taxonomy literature, and expert consultation. Lastly, the Red List of China's Biodiversity-Macrofungi was compiled via task assignment, data collection, assessed species verification, initial assessment, expert assessment, and red list compilation.

Key words: IUCN; red list categories and criteria; Possibly Extinct; macrofungi; assessment procedure

世界自然保护联盟(IUCN)物种红色名录评估 等级与标准是评价生物物种受威胁程度和灭绝风
险的最好系统之一, 在世界各国得到广泛应用 (Miller et al, 2007)。2016年，原环境保护部联合中国

收稿日期: 2019-05-23; 接受日期: 2019-07-09

基金项目: 生态环境部生物多样性调查评估项目(2019HJ2096001006)

* 共同通讯作者 Co-authors for correspondence. E-mail: lijsh@craes.org.cn; yaoyj@im.ac.cn 
科学院启动了 “中国大型真菌红色名录评估”项目, 此次评估根据大型真菌的特点, 对 IUCN等级和标 准做了必要的调整, 形成“中国大型真菌红色名录 评估等级和标准”, 并以此为基础开展评估工作, 基本步骤包括数据收集、初评、专家评审、编制红 色名录等。

\section{IUCN评估等级与标准及其修订}

本次评估主要依据IUCN Red List Categories and Criteria: Version 3.1 (IUCN, 2012a)、Guidelines for Using the IUCN Red List Categories and Criteria Version 12 (IUCN Standards and Petitions Subcommittee, 2016)和Guidelines for Application of IUCN Red List Criteria at Regional and National Levels: Version 4.0 (IUCN, 2012b)。

IUCN红色名录(3.1版)将物种濒危等级分为以 下9个: 灭绝(Extinct, EX)、野外灭绝(Extinct in the Wild, EW)、极危(Critically Endangered, CR)、濒危 (Endangered, EN)、易危 (Vulnerable, VU)、近危 (Near Threatened, NT)、无危(Least Concern, LC)、数据不足 (Data Deficient, DD)和未予评估(Not Evaluated, NE)。

按照IUCN红色名录的等级和标准, 灭绝(EX) 和野外灭绝(EW)需要有可靠的证据判定物种的最 后一个个体或野外的最后一个个体已经死亡。与动 植物不同, 大型真菌在几年甚至是上百年内都没有 任何采集或观察记录，也并不代表该物种已经灭绝， 因此很难以子实体的出现情况来判断大型真菌物 种的存在与否。大型真菌往往只在生活史中很短的 一段时间里, 在条件适宜的情况下才产生肉眼可见 的子实体，而大部分时间则以孢子、菌丝、菌索、 菌核等形式存在于土壤、水体、空气以及动植物的 活体或残体上，并可能在很长时期内都不产生子实 体。即使产生了子实体, 大型真菌的个体也明显偏 小, 很难引起注意。加之专业研究人员不足, 难以 在有限的时间内发现这些物种。要确认大型真菌物 种是否已经灭绝, 需要组织专业人员对其原产地及 可能的生境开展针对性的深入调查研究。除了采集 子实体标本, 还需要对生境中的菌丝体进行检测, 然后才能对物种灭绝与否做出判断。

“疑似灭绝” (Possibly Extinct, PE)在Guidelines for Using the IUCN Red List Categories and Criteria
Version 12中被用作“极危”等级的一个标识。针对大 型真菌的特点, 本次评估将其作为单独的红色名录 评估等级, 用于评定长期未被发现但又不能确丵证 明其已经灭绝或野外灭绝的大型真菌物种。根据 Guidelines for Using the IUCN Red List Categories and Criteria Version 12中关于疑似灭绝的说明, 这 个评估等级仍然属于受威胁的范畴(IUCN Standards and Petitions Subcommittee, 2016)。

疑似灭绝(PE): 如果对某一分类单元已知和可 能的栖息地经过长期(100年，包括不同年度和季节) 观察和全面调查, 未发现任何一个个体, 但也没有 确切证据表明其最后一个个体已经死亡，即认为该 分类单元属于疑似灭绝。

大型真菌的生物学特性与动植物显著不同。许 多动植物具有较为稳定的世代时长, 而大型真菌的 世代往往不明确，也没有固定时长。在外界条件不 适合的情况下，大型真菌能够以各种形式蛰伏几 年、几十年甚至更长的时间; 而且很多种类在形成 子实体后，其菌丝体还可以在地下存活很长时间， 真菌的一个个体甚至可生存数千年(Smith et al, 1992)。所以在本评估中采用一定的时间段代替世代 时长来计算大型真菌种群的变化, 并对IUCN物种 红色名录评估标准进行了调整。在使用标准 $\mathrm{A}$ 和 $\mathrm{C} 1$ 进行评估时，采用较长的时间段“30年内”来代替原 有的“10年内或3代内”来观测、估计、推断或猜测大 型真菌种群在过去的变化。相应地, 标准C1中“5年 或 2 代内”和“3年或1代内”也分别调整为“15年内”和 “10年内”。

此外, 大型真菌的个体数量以及成熟个体数量 等统计工作很难进行，在评估中难以直接作为判断 等级的依据。因此, 本次评估通过计算大型真菌物 种的分布范围以及观测到的子实体数量来估计、推 测或判断其数量, 并较多地使用了标准 $\mathrm{B}$ 。涉及个体 数量、小种群的标准 $\mathrm{C} 1 、 \mathrm{C} 2$ 和D1等比较少用或不 用。限于现有的数据和资料, 需要定量分析的标准 $\mathrm{E}$ 在本次评估中也未使用。

\section{2 中国大型真菌红色名录评估等级与标准}

本次评估对中国已知的大型真菌均进行了评 估，故不设未予评估等级。评估所采用的等级和标 准见图1和表1。 


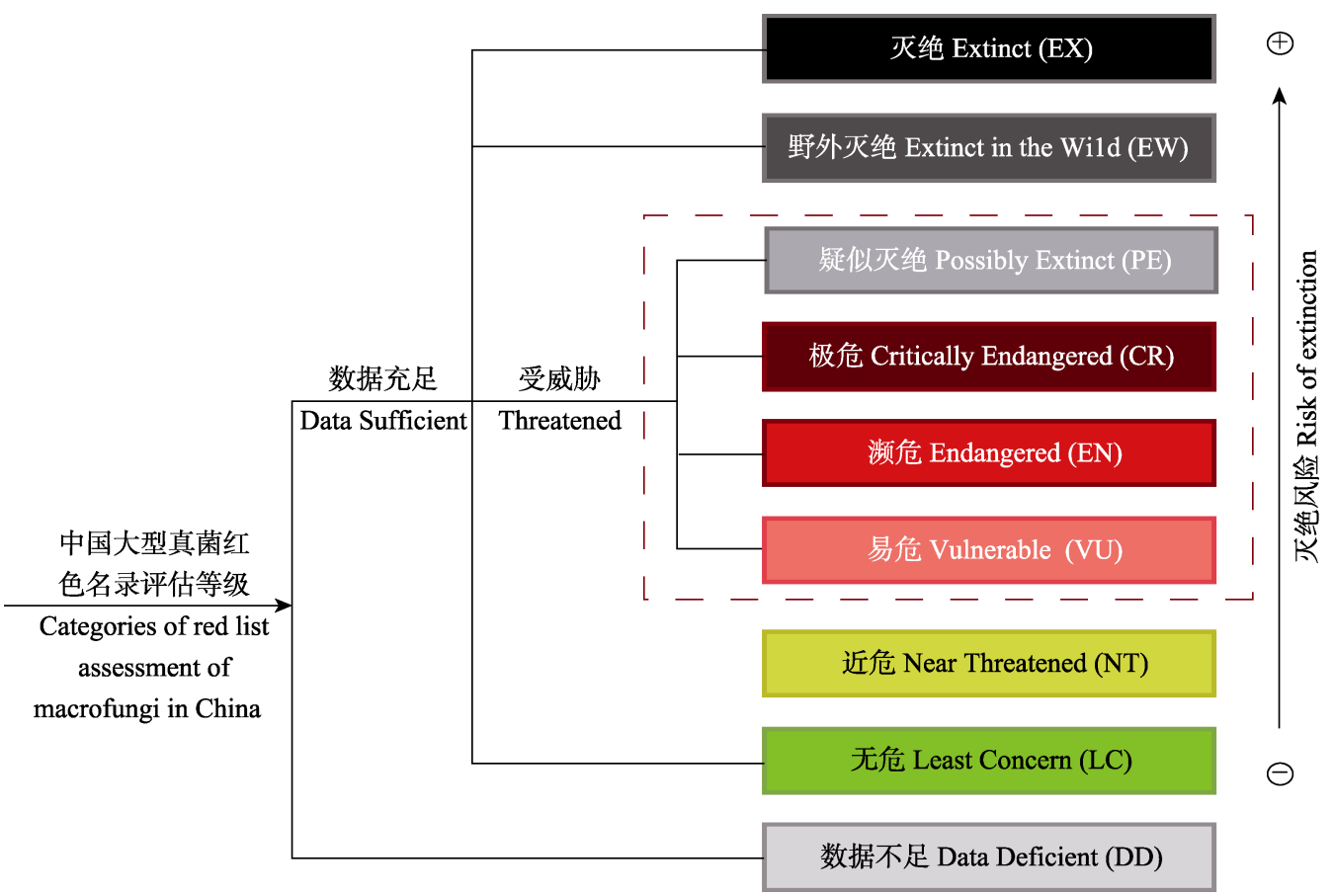

图1 中国大型真菌红色名录评估等级体系

Fig. 1 Categories of red list assessment of macrofungi in China

表1 中国大型真菌红色名录等级评估标准

Table 1 Criteria of red list assessment of macrofungi in China

$\mathrm{A}$ : 种群 ${ }^{1}$ 减少。基于 $\mathrm{A} 1$ 到 $\mathrm{A} 4$ 中任何一种在 30 年内种群减少

Population ${ }^{1}$ size reduction. Population reduction (measured over the longer of 30 years) based on any of A1 to A4

A1

A2, A3 \& A4

A1: 通过观测、估计、推断或猜测，种群在过去有所减少，其致危因素是可逆转 的、可理解并能终止的。Population reduction observed, estimated, inferred, or suspected in the past where the causes of the reduction are clearly reversible and understood and have ceased.

A2: 通过观测、估计、推断或猜测, 种群在过去有所减少, 其致危因素是不能逆 转、不能理解、也不能终止的。Population reduction observed, estimated, inferred, or suspected in the past where the causes of reduction may not have ceased or may not be understood or may not be reversible.

A3: 通过观测、估计、推断或猜测，种群在未来(最长100年内)有所减少[(a)不能用 于A3]。Population reduction projected, inferred or suspected to be met in the future (up to a maximum of 100 years) [(a) cannot be used for A3].

A4：通过观测、估计、推断或猜测，种群必须在过去和未来(最长100年内)都有所 减少, 其致危因素是不能逆转、不能理解也不能终止的。An observed, estimated, inferred, projected or suspected population reduction where the time period must include both the past and the future (up to a max. of 100 years in future), and where the causes of reduction may not have ceased or may not be understood or may not be reversible.

$\begin{array}{ll}\text { 濒危 EN } & \text { 易危 VU } \\ \geq 70 \% & \geq 50 \% \\ \geq 50 \% & \geq 30 \%\end{array}$

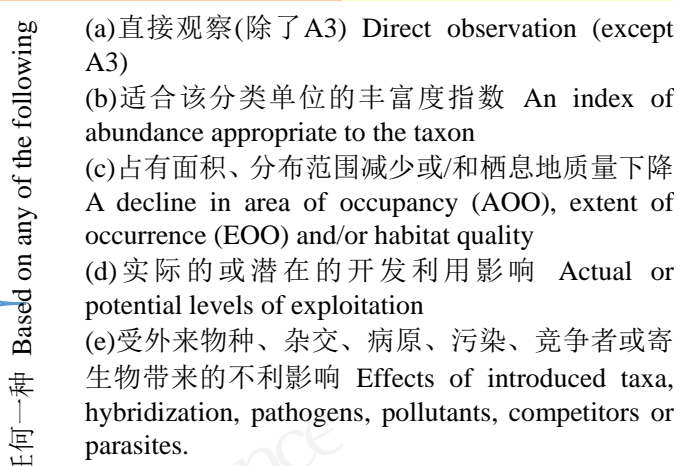

$\mathrm{B}$ : 地理分布范围减少, 或具有少数地点、严重破碎或种群波动

Geographic range in the form of either B1 (extent of occurrence) and/or B2 (area of occupancy)

B1: 分布区 Extent of occurrence (EOO) ${ }^{2}$

B2: 占有面积 Area of occupancy (AOO) ${ }^{3}$

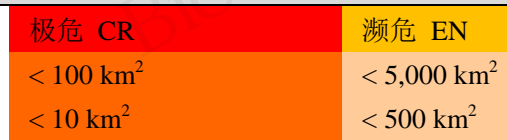

易危 VU

$<20,000 \mathrm{~km}^{2}$

$<2,000 \mathrm{~km}^{2}$

以下 3 个条件中至少满足 2 条 And at least 2 of the following 3 conditions:

(a)生境严重破碎或已知分布点数

Severely fragmented or number of locations 
表 1 (续) Table 1 (continued)

(b)以下条件中任一下降或减少 Continuing decline observed, estimated, inferred or projected in any of:

(i)分布范围 Extent of occurrence; (ii)占有面积 Area of occupancy; (iii)生境面积、范围和/或质量 Area, extent and/or quality of habitat; (iv)地点 或亚种群的数目 Number of locations or subpopulations; (v)成熟个体数 Number of mature individuals。

(c)以下条件中任一极度波动 Extreme fluctuations in any of:

(i)分布范围 Extent of occurrence; (ii)占有面积 Area of occupancy; (iii)生长地点数或亚种群数 Number of locations or subpopulations; (iv)成熟 个体数 Number of mature individuals。

C: 小种群且在衰退 Small population size and decline

成熟个体 ${ }^{4}$ 数量 Number of mature individuals

极危 CR
$<250$

濒危 EN
$<2,500$

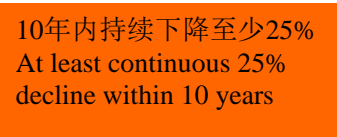

15 年内持续下降至少 20\% At least continuous $20 \%$ decline within 15 years

易危 VU
$<10,000$

30 年内持续下降至少 $10 \%$ At least continuous 10\% decline within 30 years

C2：持续下降，且符合以下至少 1 个条件 An observed, estimated, projected or inferred continuing decline and at least 1 of the following 3 conditions:

(a) (i)每个亚种群成熟个体数 Number of mature individuals in each subpopulation

(ii)一个亚种群个体数占总数的百分比

Percentage of mature individuals in one subpopulation

(b) 成熟个体数量极度波动 Extreme fluctuations in the

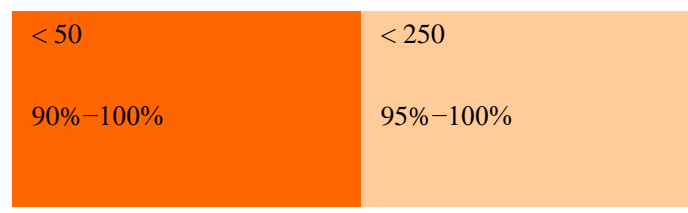

$<1,000$

$100 \%$ number of mature individuals

D: 小种群或局限分布 Very small or restricted population

D1: 种群成熟个体数 Number of mature individuals

$\begin{array}{ll}\text { 极危 CR } & \text { 濒危 EN } \\ <50 & <250\end{array}$

易危 VU

$<1,000$

种群占有面积 $<20 \mathrm{~km}^{2}$ 或 地点 $<5$ 个 Typically: $\mathrm{AOO}<20 \mathrm{~km}^{2}$ or number of locations $\leq 5$ 甚至灭绝 Only applies to the VU category restricted area future threat that could drive the taxon to CR or EX in a very short time

E: 定量分析 Quantitative analysis

\section{使用定量模型评估野外灭绝率}

Indicating the probability of extinction in the wild to be:

极危 CR
$\geq 50 \%$ (今后 10 年或三世
代内 In 10 years or 3
generations, whichever is
longer)

濒危 EN
$\geq 20 \%$ (今后20年或五世
代内 In 20 years or 5
generations, whichever is
longer)

易危 VU

$\geq 10 \%$ (今后 100 年内 In 100 years)

1 种群及种群大小: 红色名录中所谓种群有其特殊意义, 不同于生物学上一般的用法。在此定义为一个分类群的总个体数。 2 分布区: 一个分类群除流浪者(vagrancy)外, 所有已知、推论或预测位置的最短连续影像边界所包含的区域。分布区域的度量可排除此分 类群全部分布范围内不连续或跳跃的部分(例如明显不适合的栖息地)。分布区域通常可用最小凸多边形(minimum convex polygon)度量。

3 实际占有面积: 一个分类群除流浪者外在其分布区域内实际占有的面积。一个分类群在其分布区域内可能包含不适合或未占据的栖息地, 故通常不会遍布其分布区域。实际占有面积的大小为度量尺度的函数, 应考虑与分类群相关的生物学、威胁的性质以及可用的数据以选择 适当的尺度。

4 成熟个体: 指已知、估计或推测的具有生殖能力的个体数。

1 The term 'population' is used in a specific sense in the Red List Criteria that is different to its common biological usage. Population is here defined as the total number of individuals of the taxon.

2 Extent of occurrence is defined as the area contained within the shortest continuous imaginary boundary which can be drawn to encompass all the known, inferred or projected sites of present occurrence of a taxon, excluding cases of vagrancy. This measure may exclude discontinuities or disjunctions within the overall distributions of taxa (e.g. large areas of obviously unsuitable habitat). Extent of occurrence can often be measured by a minimum convex polygon.

3 Area of occupancy is defined as the area within its 'extent of occurrence' which is occupied by a taxon, excluding cases of vagrancy. The measure reflects the fact that a taxon will not usually occur throughout the area of its extent of occurrence, which may contain unsuitable or unoccupied habitats. In some cases, the area of occupancy is the smallest area essential at any stage to the survival of existing populations of a taxon. The size of the area of occupancy will be a function of the scale at which it is measured and should be at a scale appropriate to relevant biological aspects of the taxon, the nature of threats and the available data.

4 The number of mature individuals is the number of individuals known, estimated or inferred to be capable of reproduction. 


\section{3 操作程序}

\section{1 评估分工}

本次评估设立项目组、咨询专家组和评估专家 组。项目组承担项目的组织和实施, 并撰写评估报 告。咨询专家组对整个评估过程进行指导, 审定评 估对象、评估方法、标准使用、数据来源等重要问 题。评估专家组对评估名单进行审核、提出评估意 见、讨论审定有关物种的受威胁等级。

项目组分地衣型真菌、大型子囊菌和大型担子 菌3个课题组, 分别由中国科学院微生物研究所魏 江春院士、庄文颖院士和姚一建研究员负责。咨询 专家组由9位权威专家组成。评估专家组由国内 20 余个单位的130多位专家组成(姚一建, 2020)。

\section{2 收集数据}

本次大型真菌红色名录评估的主要信息来源 为中国菌物名录数据库、相关文献资料及向各类群 专家咨询的信息。收集的文献资料主要涉及大型真 菌的新种报道、物种分布、生态、保护及资源利用 等。此外, 相关领域的专家结合自身的研究成果和 经验, 提供其研究类群的最新信息, 包括物种的分 类信息、种群数量和趋势、野外生境状况、威胁因 素、利用状况和保护现状等。

通过对上述数据进行整理和归纳, 形成了中国 大型真菌物种信息表。信息表包括物种评估所需的 分类地位、地理分布、种群、野外生境状况、物种 利用、受威胁状况和原因分析、保护和繁育、威胁 因素，以及利用方式和保护现状等方面的信息。

\section{3 确定评估对象}

大型真菌是指能形成肉质、胶质或其他质地的 子实体或菌核的各类真菌, 是按照个体大小人为划 分的, 而不是系统学上的自然类群。大型真菌在基 质上或地下形成子实体, 其大小肉眼足以辨识, 可 徒手采摘。大型真菌很多种类具有较高的营养和药 用价值, 是菌物中最具有开发应用前景的重要类 群。本次大型真菌类群的选定, 经由专家初步划定, 然后查阅各种文献信息, 辅之以搜索图片, 最终确 定评估对象。

中国大型真菌红色名录评估涉及的数据资料 以中国菌物名录数据库 (http://www.fungalinfo.net) 为基础。通过广泛征求各类群研究专家意见, 在数 据库中选择地衣型真菌、大型子囊菌和大型担子菌
类群，共收集到14,511个物种名称，参考Index Fungorum数据库(http://www.indexfungorum.org)的信息 对物种学名进行订正。随后根据中国菌物名录数据 库中的数据, 对各类群的相关文献资料和信息进行 整理、核对和订正，排除分类学上存在疑问的名称 和已被处理为同物异名的名称，在此基础上确定中 国大型真菌红色名录评估对象。本次评估涵盖了我 国9,302种大型真菌，其中大型子囊菌870种、大型 担子菌6,268种、地衣型真菌2,164种，分属于 $2 门 14$ 纲62目227科1,298属(王科等, 2020)。

评估对象分为广布种和中国特有种两类，分别 采用相应的评估方式。中国特有种通过 Index Fungorum数据库中的模式标本产地信息来确定，模 式标本原产于中国且此后没有国外报道的物种为 中国特有种。同时在其他国家分布的物种为广布种。 仅在中国及周边国家分布的一些物种，由于局部分 布，在评估中采取接近于中国特有种的评估方式。

\section{4 建立评估表}

大型真菌红色名录评估信息表主要包括分类 地位、评估信息、地理分布、种群、生境、商业用 途、威胁因子和保护行动等内容。“分类地位”栏的 内容包括参评物种所属的界、门、纲、目、科、学 名、汉语学名、照片、命名人、分类备注。依据中 国大型真菌实际情况，在IUCN红色名录评估信息 表的基础上添加汉语学名和照片两项内容，该栏大 部分信息采用Index Fungorum提供的信息。“评估信 息”栏的内容包括红色名录等级与标准、评估年限、 评估日期、评定人、审定人、描述。中国大型真菌 红色名录等级采用IUCN红色名录等级，评估标准 以IUCN红色名录评估标准为参照, 结合中国大型 真菌地理分布情况形成符合我国国情的大型真菌 红色名录评估标准。评估日期和评定人为实际评估 的日期和评估人，审定人为全国参加实际评审的专 家。描述为参评物种目前所处的状态, 包括分类学 问题、分布范围、栖息地情况、种群情况、人类活 动影响等内容。“地理分布”栏内容包括分布区、分 布国家，其中分布区主要为国内的分布情况，分布 国家为参评物种的世界分布情况，该栏内容根据中 国菌物名录数据库中的信息汇总而成。“种群”栏内 容包括种群数量、种群趋势和附加信息，该栏的信 息在大部分大型真菌中较难判断，因此大多为“未 知”, 如有可靠参考资料则按其信息来源填写。“生 
境” 栏内容包括生境、生态系统、世代年限, 主要由 中国菌物名录数据库提供。“商业用途”栏体现参评 物种的商业用途, 也由中国菌物名录数据库提供。 “威胁因子”栏填写主要的威胁因子，即参评物种目 前可能会受到的威胁，该栏是对评估信息的整理汇 总。“保护行动”栏提供参评物种目前所处的状况以 及针对所受的威胁因子而采取的必要保护措施, 在 评估过程中整理总结(附录1)。

\section{5 初步评估}

本项目 3 个课题组依据中国菌物名录数据库中 提取的信息, 结合地衣型真菌、大型子囊菌和大型 担子菌自身特点, 以及我国资源研究和保护现状, 参照前文所述的中国大型真菌红色名录评估等级 与标准, 拟定具体实施方法, 对相关物种逐一进行 评估。

根据 IUCN 物种红色名录评估等级和标准 (IUCN, 2012a), 按照大型真菌各个参评物种的地理 分布情况, 将大型真菌分为单一分布、分散分布和 集中分布。

初步评估主要采用了“初步筛选归类”和“逐一 分析评估”相结合的方式。“初步篮选归类”主要是根 据大型真菌在中国的分布记录, 以单一分布 (县级 行政区域)、分散分布、集中分布三种类型结合中国 特有种和世界广布种(或区域分布种)的划分对物种 进行初步评估。“逐一分析评估”是基于初篮的结果, 对需要全面分析的大型真菌进行逐一评估。

(1)单一分布

a. 仅分布于 1 个县级行政区域且为中国特有种, 则其受威胁等级初步评为近危或以上。

b. 仅分布于 1 个县级行政区域且为世界广布种 (或区域分布种), 则将其评为数据不足。

(2)分散分布

a. 分布于 2 个及以上县级行政区，并且各分布 点(县)之间的距离较大或分跨不同的省份, 则将其 初步评为无危。

b. 包括世界广布种(或区域分布种)和中国特 有种, 除非有明确证据表明其分布面积在缩小、种 群在衰退，均初步评为无危。

(3)集中分布

分布于 2 个及以上县级行政区, 并且 2 个分布点 (县)或多个点(县)集中分布在同一地区或在同一省 份内: a. 评估物种为中国特有种或分布报道记录仅 在1973年以前，其受威胁等级初步评为近危或以 上。

b. 若评估物种为世界广布种(或区域分布种), 则将其评为数据不足。

c. 若为 10 年以内发表的新种, 除特别说明外, 一般列为数据不足。

对上述初步篎选归类过程中被列为近危及受 威胁程度更高的物种, 依据中国大型真菌红色名录 等级和标准进行深入的分析评估，确定初评等级。 根据初步评估的结果形成了《中国大型真菌红色名 录初评等级》, 提供给评估专家组进行通讯评审。

\section{6 建立评估网站}

项目工作组为中国大型真菌红色名录评估项目 建立了专门的网站(http://124.16.146.175:8081/revise_ system/portal.php), 并根据评审工作中数据信息公 开情况分为目前可公开和不公开两类内容, 可公开 内容设在“中国大型真菌红色名录评估项目”网站, 评审专家以及对评审工作感兴趣的人士可随时浏 览此网站中的相关内容。该网站首页报道项目最新 进展情况(图2)。同时可通过首页右侧链接进入 “中 国大型真菌红色名录评审系统”, 登录后进入评审 界面(图3)。评审专家可通过其中的“评估列表”、“评 估流程”、“标准与方法”、“评估类群”、“评估指南” 等栏目获取相关信息和评估指导。此外，评审系统 的“联系我们”栏包含项目工作组地址、联系电话以 及电子邮箱。项目工作组随时响应和解决评审专家 在评审过程中提出的问题和遇到的困难。

项目工作组通过电子邮件和手机短信的形式 给评审专家发送邀请函，同时提供专家登入评估网 页的用户名和密码，供评审专家登录到“中国大型真 菌红色名录评审”界面。专家可通过“评估列表”查看 需要评审和已经评审过的物种列表。进行评审时, 在需要评审的物种列表中继续点击“评审”按钮即进 入其对应物种的“物种评估信息表”。对物种进行评 审和修改后, 点击“保存”按钮即可存储评审结果。 当对某一物种无法进行可靠的评审时，专家可在相 应的参评物种列表操作列中点击“删除”按钮, 将该 物种退回项目工作组。在完成评审后，点击“提交” 按钮, 即可正式提交已经保存的物种评估信息。

\section{7 专家评审}

每个物种的评估结果由参与初评以外的学者 


\section{中国大型真菌红色名录评估项目}

\section{首页 IUCN红色名录 项目简介| 评估流程}

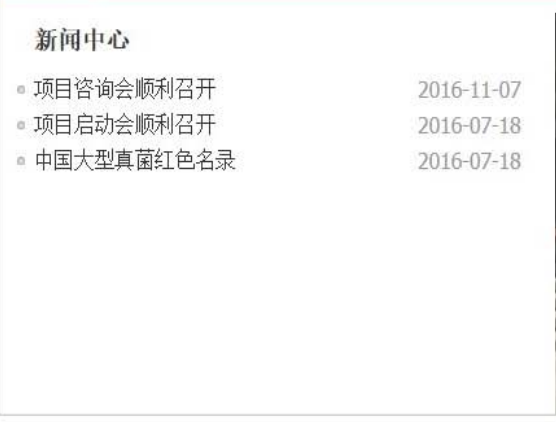

Powered by Discuz! X3.2

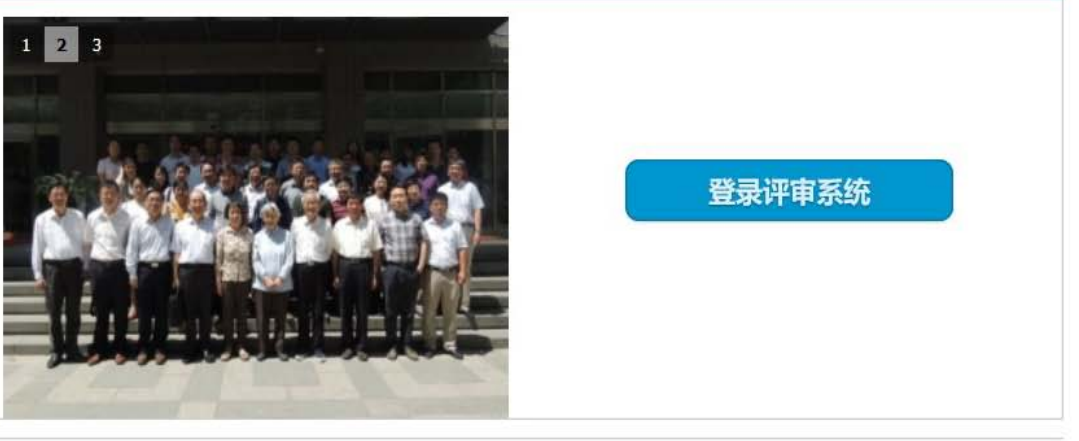

门户管理员登录 | 评估系统管理员登录 | 中国大型真菌红色名录评估项目

图2 中国大型真菌红色名录评估网站首页

Fig. 2 Homepage of red list assessment of macrofungi in China website

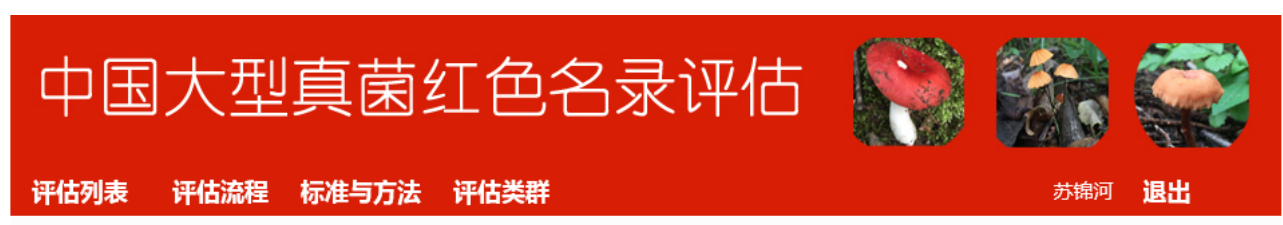

\begin{tabular}{|c|c|c|c|c|c|}
\hline \multicolumn{2}{|r|}{ 末审阅 } & 已审阅 & \multirow[b]{2}{*}{ 时间 } & \multirow{2}{*}{\multicolumn{2}{|c|}{ 操作 }} \\
\hline 序号 & 种名 & 作者 & & & \\
\hline 1 & Lirula nervisequa & (DC.) Darker & $2016-08-0122: 38: 57$ & 评审 & 删除 \\
\hline 2 & $\begin{array}{c}\text { Meliola } \\
\text { camelliicola }\end{array}$ & W. Yamam. & $2016-08-0122: 38: 57$ & 评审 & 删除 \\
\hline 3 & $\begin{array}{c}\text { Paraniesslia } \\
\text { aquatica }\end{array}$ & L. Cai \& K.D. Hyde & 2016-08-01 22:38:57 & 评审 & 删除 \\
\hline 4 & $\begin{array}{l}\text { Pestalotiopsis } \\
\text { lambertiae }\end{array}$ & $\begin{array}{c}\text { (Petr.) A.R. Liu, T. Xu \& } \\
\text { L.D. Guo }\end{array}$ & $2016-08-01$ 22:38:57 & 评审 & 删除 \\
\hline 5 & $\begin{array}{l}\text { Fusarium } \\
\text { caeruleum }\end{array}$ & Lib. ex Sacc. & $2016-08-0122: 38: 57$ & 评审 & 删除 \\
\hline 6 & Oidiopsis solani & $\begin{array}{l}\text { N. Ahmad, A.K. Sarbhoy, } \\
\text { Kamal \& D.K. Agarwal }\end{array}$ & $2016-08-0122: 38: 57$ & 评审 & 删除 \\
\hline 7 & $\begin{array}{c}\text { Ulocladium } \\
\text { zantedeschiae }\end{array}$ & X.G. Zhang \& T.Y. Zhang & $2016-08-0122: 38: 57$ & 评审 & 删除 \\
\hline 8 & $\begin{array}{l}\text { Coccomyces } \\
\text { illiciicola }\end{array}$ & $\begin{array}{l}\text { H.Y. Liu, Y.R. Lin \& C.T. } \\
\text { Xiang }\end{array}$ & $2016-08-01$ 22:38:57 & 评审 & 删除 \\
\hline 9 & $\begin{array}{l}\text { Trichothecium } \\
\text { sympodiale }\end{array}$ & $\begin{array}{c}\text { Summerb., Seifert \& } \\
\text { Schroers }\end{array}$ & $2016-08-01$ 22:38:57 & 评审 & 删除 \\
\hline 10 & Xylaria ficicola & $\begin{array}{l}\text { Hai X. Ma, Lar.N. } \\
\text { Vassiljeva \& Yu Li }\end{array}$ & $2016-08-0122: 38: 57$ & 评审 & 删除 \\
\hline
\end{tabular}

Copyright $\odot 2016$ 中国科学院微生物所菌物标本馆 All Rights Reserved

图3 中国大型真菌红色名录评估网站评审系统

Fig. 3 Review system of red list assessment of macrofungi in China website

进行复查和审核。项目组邀请了咨询专家组和评估 专家组的专家对初评结果进行评审, 完善评估依据, 补充评估信息，以保证评估结果的准确性。
专家评审重点关注初评过程中被评为受威胁 等级和近危的物种以及可能遗漏的受威胁物种。评 审包括专家组通讯评审、专家咨询会议审议和专家 
通讯复审等程序。

(1)专家组通讯评审。借助所构建的评估网站, 依据专家组成员的研究领域, 针对各个物种的初步 评估结果邀请相关专家进行通讯评审, 进一步补充 评估信息，完善评估依据。根据专家评审意见对大 型真菌物种评估报告进行补充修改, 再请专家审 核。经过通讯评审和补充修改, 汇总为大型真菌初 步红色名录。

(2)专家咨询会议审议。通过召开咨询会议, 邀 请相关专家, 特别是关键类群的研究专家进行会议 审议。来自全国20余个单位的60余位大型真菌研究专 家参加了会审。根据评审专家的意见, 对评估结果 进行修改和调整, 并补充相关信息, 完善评估结果。

(3)专家通讯复审。邀请会审专家再次在评估网 站进行复审，核实受威胁物种的分类地位、分布情 况、野外生境状况等信息, 进一步确认会审物种的 受威胁等级。

\section{8 编制红色名录和受威胁物种评估说明}

在专家会审和专家通讯复审意见的基础上，按 照统一格式, 整理每个物种的信息, 编制形成《中 国生物多样性红色名录一大型真菌卷》，并就受 威胁物种做出评估说明。受威胁物种评估说明的内 容包括物种学名、中文名、科名、中文科名、评估 结果(受威胁等级及标准)、受威胁因素、参考文献、 图片、评估人、复核人等信息(附录1)。

\section{4 展望}

此次大型真菌红色名录评估依据本文所述的 方法与流程开展, 取得了阶段性成果, 但实际操作 当中仍存在问题和不足之处。项目组依照所收集的 现有菌物信息、根据中国大型真菌红色名录评估标 准提出了 “初步篮选归类”的方法, 但受制于数据类 型的限制, 这一方法的设计主要依据了标准B (表1), 而对其余4条标准参考较少。2019年, 全国范围的大 型真菌多样性调查、观测与评估项目已逐步开展, 经由这项工作可获得丰富的大型真菌野外分布、种 群变化等数据(李熠等, 2020)。在积累充足数据的基
础上，大型真菌红色名录的评估方法可进一步补充 和完善, 其评估结果也将能更准确地反映某一物种 的受威胁状态。

\section{参考文献}

IUCN (2012a) IUCN Red List Categories and Criteria, Version 3.1, 2nd edn. IUCN, Gland, Switzerland \& Cambridge, UK.

IUCN (2012b) Guidelines for Application of IUCN Red List Criteria at Regional and National Levels, Version 4.0. IUCN, Gland, Switzerland \& Cambridge, UK.

IUCN Standards and Petitions Subcommittee (2016) Guidelines for Using the IUCN Red List Categories and Criteria, Version 12. The Standards and Petitions Subcommittee. http://www.iucnredlist.org/documents/RedListGuidelines. pdf/. (accessed on 2016-09-08)

Li Y, Liu DM, Wang K, Wu HJ, Cai L, Cai L, Li JS, Yao YJ (2020) Red list assessment of macrofungi in China: Challenges and measures. Biodiversity Science, 28, 66-73. (in Chinese with English abstract) [李熠, 刘冬梅, 王科, 吴海 军, 蔡蕾, 蔡否, 李俊生, 姚一建 (2020) 中国大型真菌 红色名录评估中存在的问题及今后的对策. 生物多样性, 28, 66-73.]

Miller RM, Rodríguez JP, Aniskowicz-Fowler T, Bambaradeniya C, Boles R, Eaton MA, Gärdenfors U, Keller V, Molur S, Walker S, Pollock C (2007) National threatened species listing based on IUCN criteria and regional guidelines: Current status and future perspectives. Conservation Biology, 21, 684-696.

Smith ML, Bruhn JN, Anderson JB (1992) The fungus Armillaria bulbosa is among the largest and oldest living organisms. Nature, 356, 428-431.

Wang K, Zhao MJ, Su JH, Yang L, Deng H, Wang YH, Wu HJ, Li Y, Wu HM, Wei XD, Wei TZ, Cai L, Yao YJ (2020) The use of Checklist of Fungi in China database in the red list assessment of macrofungi in China. Biodiversity Science, 28, 74-98. (in Chinese with English abstract) [王科, 赵明 君, 苏锦河, 杨柳, 邓红, 王永会, 吴海军, 李熠, 吴红 梅, 卫晓丹, 魏铁铮, 蔡磊, 姚一建 (2020) 中国菌物名 录数据库在大型真菌红色名录编制中的作用. 生物多样 性, 28, 74-98.]

Yao YJ (2020) Red list assessment of macrofungi in China. Biodiversity Science, 28, 1-3. (in Chinese) [姚一建 (2020) 中国大型真菌红色名录评估. 生物多样性, 28, 1-3.]

(责任编委: 杨祝良 责任编辑: 闵文杰) 


\section{附录1 物种评估信息表模板}

Appendix 1 Template of assessed species information

\section{云南假地舌菌 Hemiglossum yunnanense}

\begin{tabular}{lllll}
\hline 分类地位 Taxonomy & & & & \\
\hline 界 Kingdom & 门 Phylum & 纲 Class & 目 Order & 科 Family \\
真菌界 Fungi & 子囊菌门 Ascomycota & 锤舌菌纲 Leotiomycetes & 未定目 Incertae sedis & 未定科 Incertae sedis \\
学名 Scientific Name & Hemiglossum yunnanense & & \\
汉语学名 Chinese Name & 云南假地舌菌 \\
命名人 Species Authority & Pat. & \\
同物异名 Synonym(s) & $=$ Microglossum yunnanense (Pat.) Sacc. \\
分类备注 Taxonomic Notes & 该物种为1890年基于采自云南大理的单一标本发表的新种, 目前全世界仅存一份标本, \\
& 此后100多年里再无新的采集记录。 \\
\hline
\end{tabular}

\section{评估信息 Assessment Information}

\begin{tabular}{ll}
\hline 红色名录等级及标准 Red List Category \& Criteria & 疑似灭绝 PE \\
发布年份 Year Published & 2018 \\
评估日期 Date Assessed & $2016 / 9 / 27$ \\
评定人 Assessor(s) & 庄文颖, 李熠 \\
审定人 Reviewer(s) & 徐阿生, 姚一建 \\
描述 Justification & 该物种自Patouillard (1890)发表后再没有被采集到。我国真菌学研究人员十分关注此物 \\
& 种, 多次前往模式产地(云南大理苍山)开展调查, 都未再发现。随着人类活动的影响和环 \\
& 境变迁, 该物种可能已处于极度濒危或更加危险的灭绝状态。本次评估将该物种列为 \\
& “疑似灭绝(PE)”。该物种种群在过去减少的幅度可能超过 $90 \%$, 栖息地质量下降, 分布面 \\
& 积 < $100 \mathrm{~km}^{2}$, 生境严重破碎。
\end{tabular}

\begin{tabular}{ll}
\hline 地理分布 Geographic Range & \\
\hline 分布区 Range Description & 云南 \\
分布国家 Countries Occurrence & 中国 \\
分布图 Range Map & \\
\hline
\end{tabular}

\section{种群 Population}

\begin{tabular}{ll}
\hline 种群数量 Population Size & 减少 \\
种群趋势 Current Population Trend & 衰退 \\
附件信息 Additional Data & 无
\end{tabular}

\begin{tabular}{|c|c|}
\hline 生境 Habitat and Ecology & \\
\hline 生境 Habitat and Ecology & \\
\hline 生态系统 Ecosystems & \\
\hline 世代年限 Generation Length (years) & \\
\hline 商业用途 Use and Trade & \\
\hline 商业用途 Use and Trade & 无 \\
\hline 威胁因子 Threats & $a n$ \\
\hline 主要威胁因子 Major Threat(s) & 中国特有种, 分布区域狭小, 种群数量有限。 \\
\hline 保护行动 Conservation Actions & 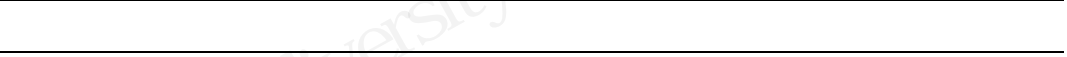 \\
\hline 保护行动 Conservation Actions & $\begin{array}{l}\text { 该物种未被列入国家保护物种, 其分布地未被保护区覆盖。为了彻底澄清该物种的受威 } \\
\text { 胁状态, 建议启动针对该物种的实地调查和监测, 并考虑必要的保护措施。 } \\
\end{array}$ \\
\hline 参考文献 Citation & 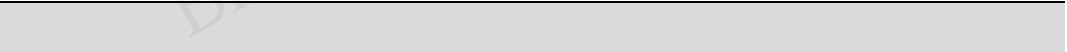 \\
\hline
\end{tabular}

